\title{
Geomorphosite Valorization a View to Sustainable Development: Case of Ait Hajji, Oued Boulahmayel Valley, Central Morocco
}

\author{
Nahraoui Fatima Zahra, El Wartiti Mohamed, Zahraoui Mohamed, Dabi Sanaa \\ Laboratory of Applied Geology, Department of Geology, Faculty of Sciences Rabat, \\ Université Mohammed V-Agdal, Rabat, Morocco \\ E-mail: f.z.nahraoui@gmail.com \\ Received July 31, 2010; revised September 2, 2010; accepted September 8, 2010
}

\begin{abstract}
The Pleistocene Fluvial-lacustrine of Ait Hajji Formation is located in South East of Tiddas, and in the Quaternary deposits of the Moroccan Central Plateau. These outcrops represent on a geomorphosite of great importance for the study of geological heritage, and for a natural eco-tourism valorization in Morocco. For to aim a natural tourism promotion, for indigenous peoples, this geomorphosite in question has an fluorescent and dense flora with a diversified fauna in the heart of one Ordovician quartzite bar and Devonian limestone ridges. In Oued Boulahmayel geomorphosite contains a memory geological Formation of a Pleistocene episode, beginning firstly by a dynamic fluviatil land synchronous with a local volcanic activity (Phonolite nephelinc) replaced by a lake sedimentation related to the formation of a dam natural, created a few hundred meters downstream from Boulahmayel. For valorizing of the hinterland of the plains towns, it is necessary to develop a geo-eco-tourism integrated who provide its harvest and will argue the benefits resources of rural people of high-mountains in their own environment. It is proposed in the perspective to initiate a sustainable development approach, while ensuring the conservation and ensure the continued natural existence of the surroundings environments and to appreciate the potential of the region. Thus that beauty hidden in the hinterland upstream to a tourist eager for discoveries, to encourage them to practice their stay as short as it is, in a safe space and very quiet. In order to materialize the concept of geo-eco-tourism, we must deploy the efforts of local people, policy makers and scientists in order to produce tourist maps with different interesting routes, to implant signal panels, to develop tracks campsites and trails within the forests, creating shelters and rest houses in private homes, as well as provide training for specialized guide's rescuers.
\end{abstract}

Keywords: Geological Site, Geomorphology, Central Morocco, Ait Hajji, Oued Boulahmayel, Fluvial-Lacustrine Formations, Geo-Eco-Tourism, Sustainable Development

\section{Introduction}

Throughout the world there are many examples of rocks, fossils and landscapes showing the history of the Earth, like geotope and geofacies [1]. Some are exceptionally beautiful and/or spectacular, others are more common but essential to understanding the evolution of our planet. These later are considered important tools for enhancing the natural geological heritage, and for public awareness on environmental issues, for enhance the value of landscape eco-tourism and to serve as demonstration tools development sustainable. Currently there are a large number of geomorphosite of great importance and some of them were classified as IUCN (International Union for Conservation of Nature) such as overlap of Glarus in Switzerland [2], Park Natural de Cazorla in Las Villas [3] or the volcanoes in Australia [4].

In recent years, Morocco like any other country has attached a great importance to the geomorphosite such as a national heritage for providing a geo-écoutouristic activity in these natural areas [5-7]. These last offer for these visitors' fantastic occasions for the admiration of wealth natural and teaching professional of the conservation importance to geomorphosite and also for the pres- 
ervation of local heritage.

In Morocco, more specifically in Central Morocco and in southern of Tiddas include many landscapes of great importance that deserve particular attention, especially that of river-lake series Plio-Quaternary of Ait Hajji. Thus, the aim of the present paper is to develop several of geomorphosite characteristic of socio-cultural viewpoint and ecotourism for a sustainable development and to explain how to better safeguard natural richness in this geomorphosite of Ait Hajji.

\section{Geographic and Stratigraphic Background}

The Ait Hajji Formation is located at $12 \mathrm{~km}$ in southern of Tiddas (Figure 1), about $200 \mathrm{~m}$ crossing the track leading from Moulay Bouazza and Oued Boulahmayel, with Lambert coordinates: $\mathrm{X}=426,6$ et $\mathrm{Y}=318,7$ [8].

\subsection{Geological Framework}

This landscape is part of the succession of formations fluvial-lacustrine of Ait Hajji rever basin Figures 2, 3 these last are located on the right bank of the Oued Boulahmayel and they occupy the bench of a large subcircular depression bounded by a thick edges of Ordovician quartzite who outcropping in sandstone-pelitic deposits Devonian [8].

\subsection{Startigraphic Description}

It is a fluvial-lacustrine Formation poorly consolidated, characterized by a sequential vertical evolution well marked. This Pleistocene Formation is consists of two lithological units with different colors (Figure 4). The first one, greyish, is formed by staple deposits composed of blocks of gravel and sandstone. In addition, there are granitic pebble, basalt and metamorphic rocks. These elements are linked by a sandy matrix. Also, this same group often shows the chenal marks and hardground separating the sequential units. The second set is yellowish color and thickness of $25 \mathrm{~m}$. It consists of coarse sand to fin and laminated limestone, with rares fossils of continental vegetal and gastropods [8]. The entire series shows a tectonic signature due to two generations of faults (Figure 5): the first is synsedimentary; the second was more later [8].

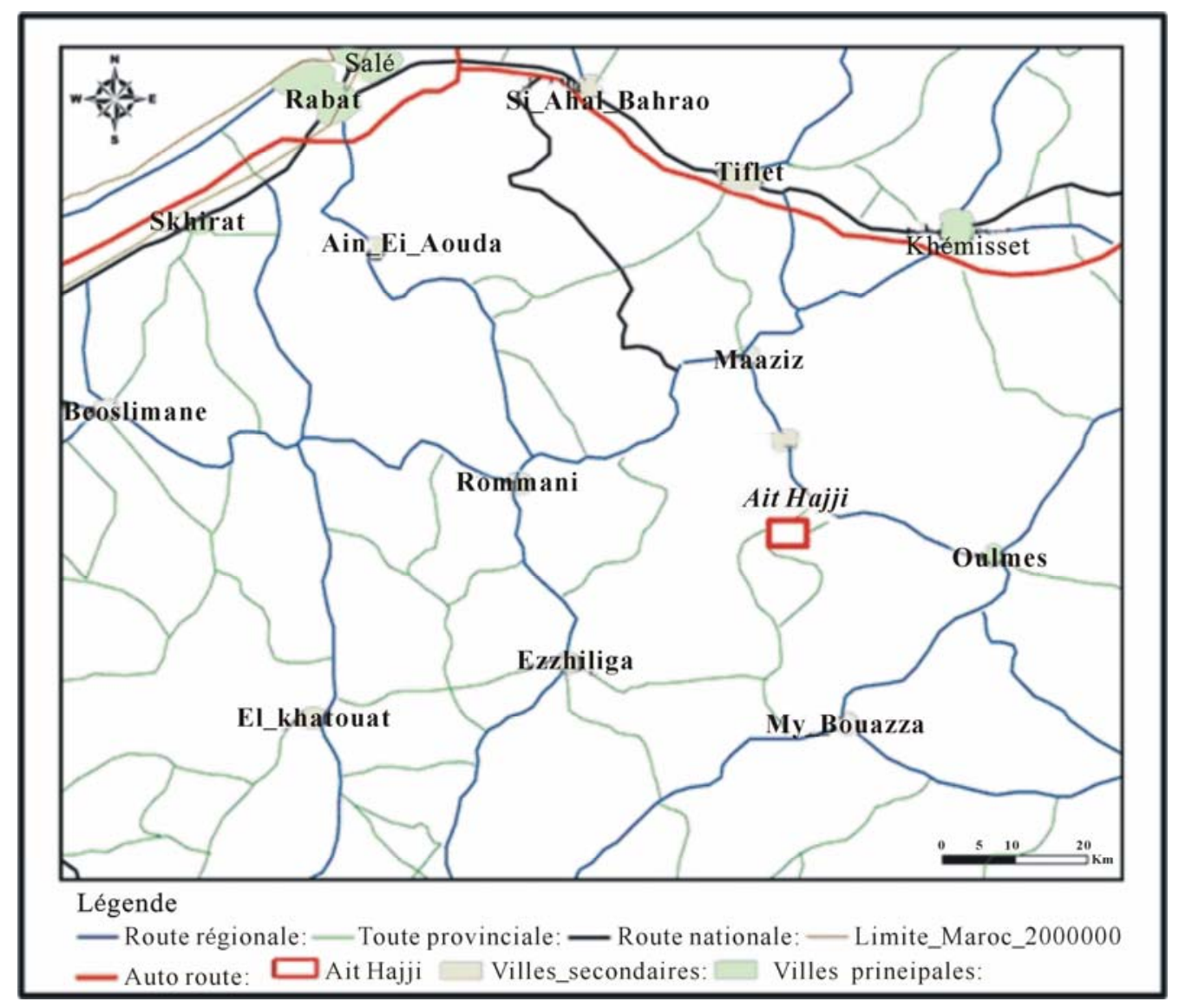

Figure 1. General information of Ait Hajji geomorphosit. 

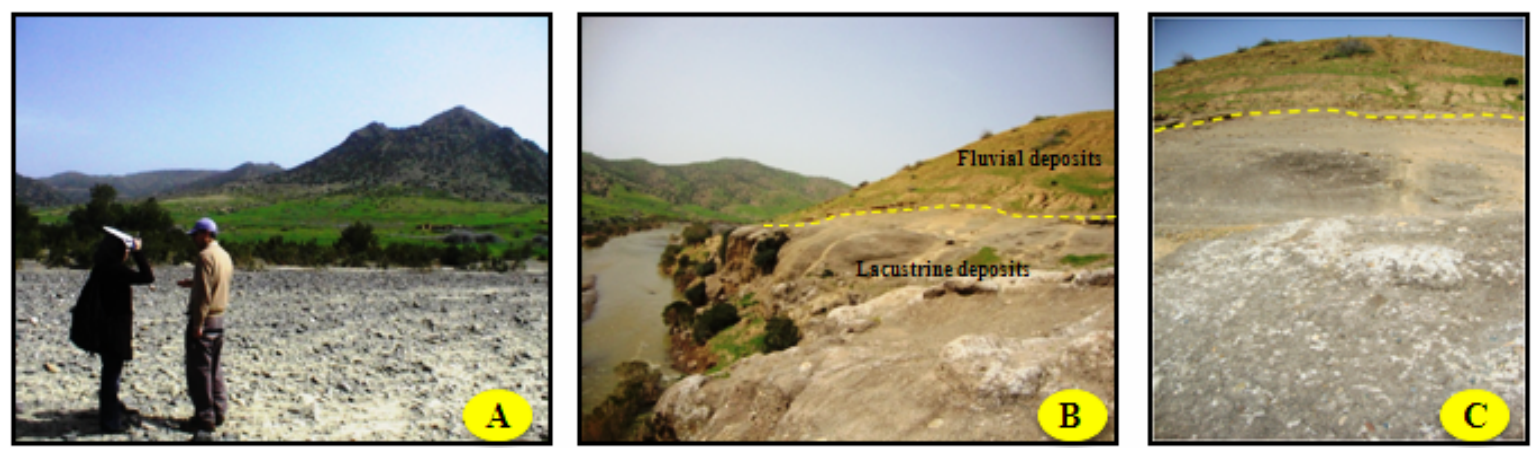

Figure 2. General information of Ait Hajji geomorphosit: panoramic view of Ait Hajji gemorphosit (a), view showing the fluvial deposits overlain by lacustrine deposits (b), view of succession the fluvio-lacustrine formations (right bank of boulahmayel oued) (c).

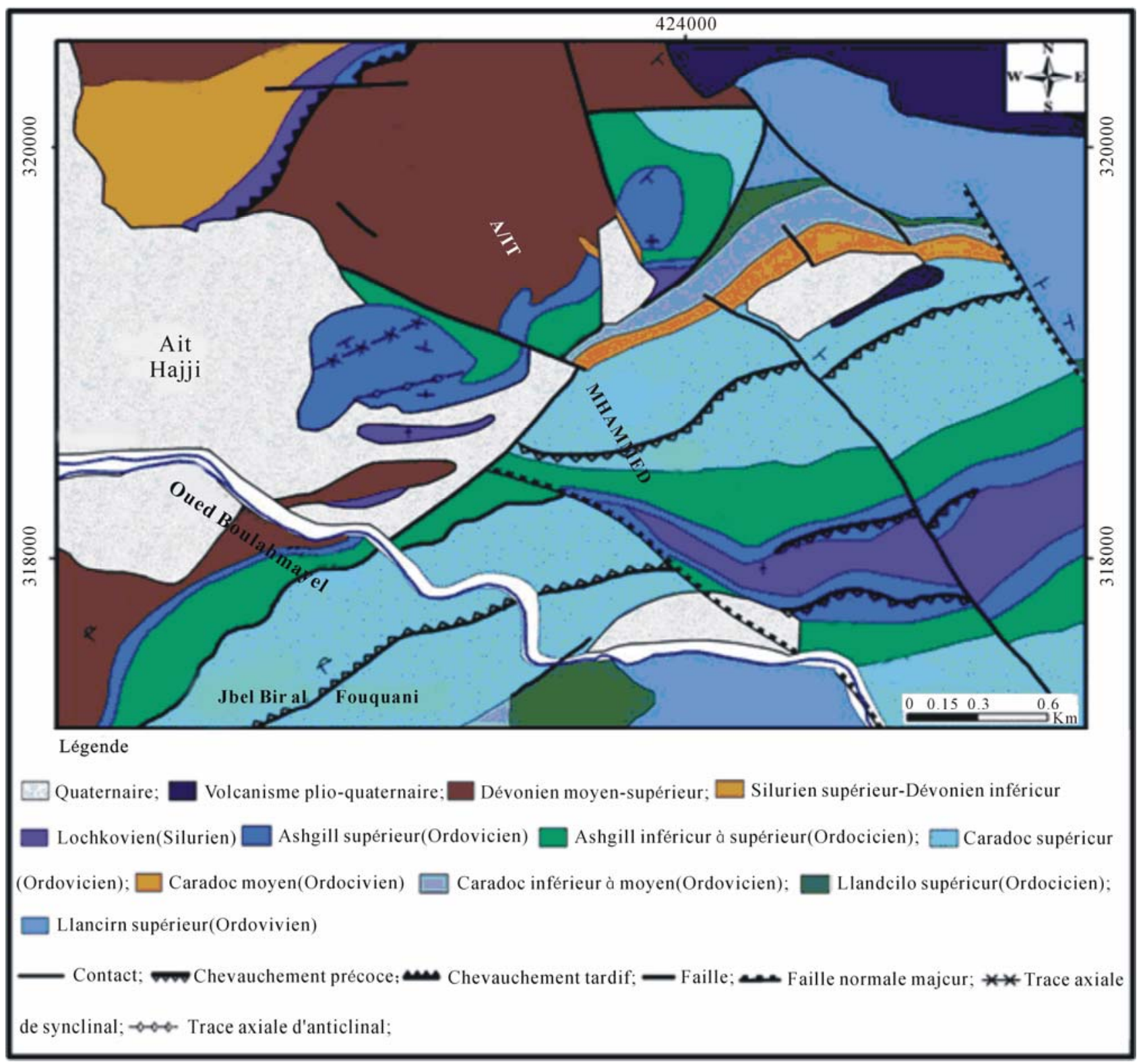

Figure 3. Geological framework of Ait Hajji geomorphosit. 


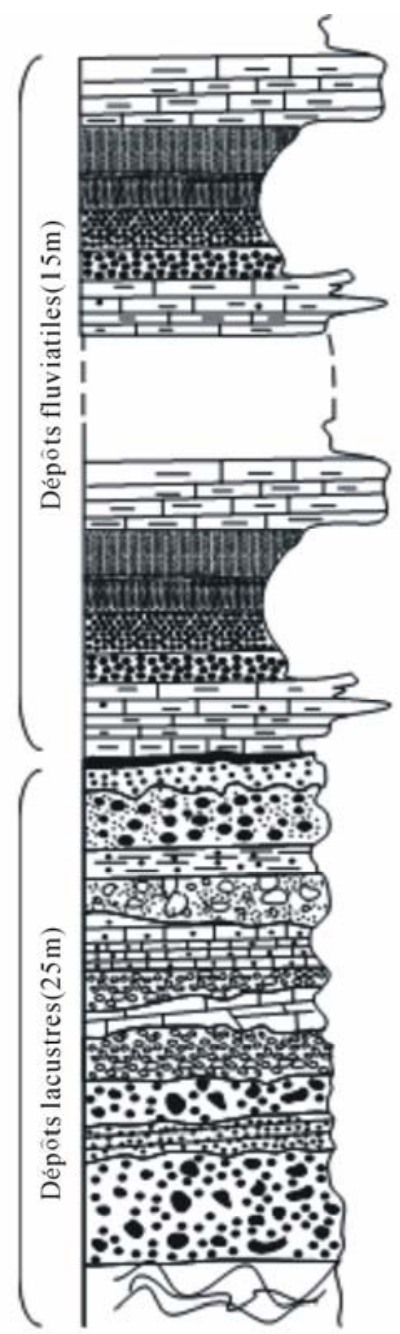

Légende

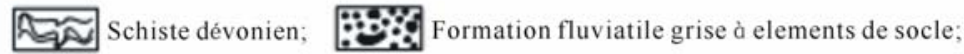

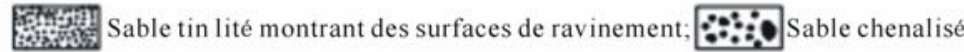
à gros blocs de socle; calcareuses à cncroutement tement Ferrugineux Sable tufacé à elements colcanique; Sable grossier; $\square$ surface de

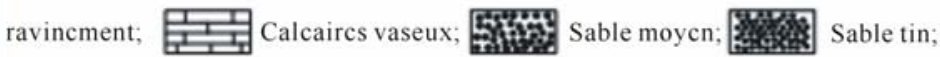

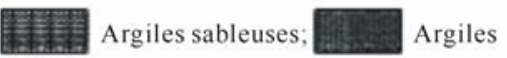

Figure 4. Composite stratigraphic column of Ait Hajji deposits.

\section{Results and Discussions}

The Geomorphology of Ait Hajji is located on the right bank of the oued Boulahmayel (Top of Bou Regreg) and in the midst of a great depression subcircular. It is surrounded by reliefs of Paleozoic land covering a geologi- cal formation that begins firstly by a fluviatile series synchronous with the local volcanic activity followed by lacustrine deposits.

The spatio-temporal organization of these fluviallacustrine indicates that:

- The fluvial deposits show the existence a feeding 
from reliefs in the depression Ait Hajji, where flowed Boulahmayel Oued.

- The lake deposits show an abrupt change in fluvial dynamics. This leads us to believe that the main cause of this change is the introduction of naturel obstructions.

The model proposed for the Boulahmayel Valley in the upstream Bouregreg, indicates the existence of nephelinic phonolite flow, with $10-20 \mathrm{~m}$ thick, was the cause of the establishment of a natural dam. Based on $\mathrm{K} / \mathrm{Ar}$ data, the Plio-Quaternary phonolitic has been estimated between 2.8 and 0.31 Ma [9] and more precisely between 1.8 and $0.89 \mathrm{Ma}$ [10].

Thus, the natural roadblock of phonolite was responsible for blocking the flow of water from the Oued Boulahmayel firstly and then installation of a lake in the same depression who is surrounded by land Paleozoic in relief.

However, this Ait Hajji geomorphosite has some environmental and social problems. Among these problems is the illegal exploitation of sand, gravel and pebbles. Indeed, in the meandering Boulahmayel Oued, the extraction activity, and exploitation of the sand, gravel and pebbles made by trucks despites the prohibition of removal of the latter, which results in the widening the channel of the Oued, increase of vulnerability, and loss of land will be increased.

Another problem that arises for the same site, it's the flooding of Boulahmayel Oued. The discharge of coarse material carried by the floods on the western side of the river whose topography is flat constitutes a negative impact on the terraces that are cultivated.

These last lose their silty-clay sediments, fertile for farming and that are dominated by coarses conglomerates, harmful for agricultural practices, as is the case this year (Winter 2010).

From these various problems listed above, it is therefore necessary to decide one strategy for better safeguarding for such to geomorphosite which present some property natural and economic. Consequently, the intervention of local authorities must be strict and tough for to stop that kind of irrational exploitation. Moreover, among these backup strategies we can propose solutions that may constrain the flooding of Boulahmayel Oued by constructing a dam on the right bank and to build a real bridge instead of partial bridge washed away by floods such as this year (Winter 2010); also the construction of dam or some Restraint-Water upstream in the aim to moderate the force of a flooded and coarse sediment transport and their deposition on agricultural land.

It's in this context that the geo-eco-tourism concept should be put in evidence by developing the efforts of local people, policy makers and scientists in order to

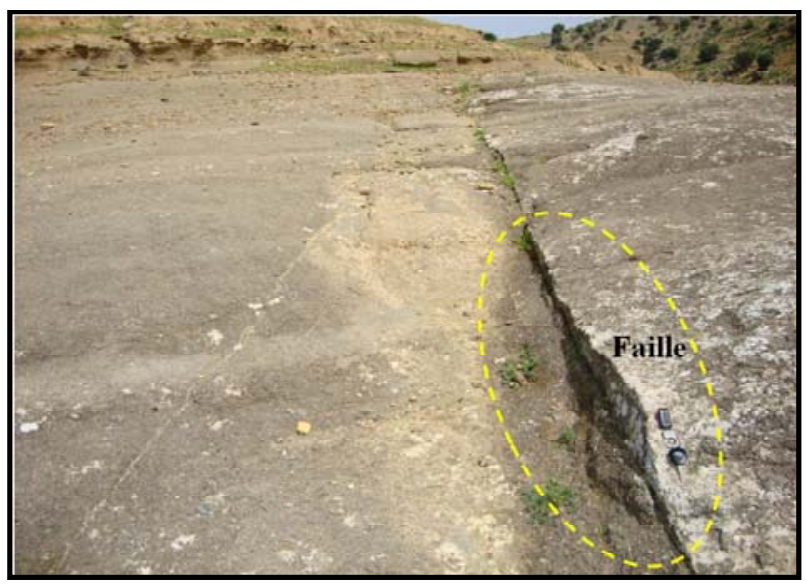

Figure 5. Faulted structure of fluvial series in the Ait Hajji geomorphosite.

produce tourist maps with different interesting routes, the implantation of sign panel, develop the trails campsite within the forest, creating shelters and rest houses, and provide the training of guides specialized.

\section{Conclusions}

From the perspective of sustainable development, Morocco was conscious of the importance of the natural richness development, including of the Ait Hajji geomorphosite, which can be valued on several level:

1) On the academic and scientific plane: view the geological history significance, of this geomorphosite, this last been subject of several national research and publications.

2) On the education plane: the geological structures of Ait Hajji geomorphosite may can to play an important educational tool for teaching in these different forms (university, specialist, social promotion ...).

3) On geo-touristic plan: the beauty of nature in the upstream hinterland of this geomorphosite can be a source of tourist attraction and thirsty people for natural discoveries and geographic areas enjoy the magnificent and peaceful spaces.

Thus, in order to achieve the objectives proposed for the geomorphosite Ait Hajji, including a geo-eco-touristic vision, it is necessary to deploy all popular efforts and authoritarian for to succeed of the develop and protection of this geomorphosite from damage as much natural as anthropogenic.

\section{Acknowledgements}

We would like to thank the referee for their constructive comments and suggestions which significantly improved our manuscript. 


\section{References}

[1] J. C. Filleron, "Le Paysage, Cela Existe, Meme Lorsque Je Ne le Regarde pas ou Quelques REflexions surles Pratiques PaysagEres des Geographes, Pôle Universitaire Européen de Montpellier,” Journée Scientifique "le paysage entre culture et nature", 1998, pp. 1-12.

[2] International Union for Conservation of Nature, "Convention Concernant la Protection du Patrimoine Mondial, Culturel et Naturel," $29^{\text {ème }}$ Session, Afrique du Sud, 2005, p. 67.

[3] R. Jimenez Espinosa, L. M. Nieto, P. Alfaro Garcia, J. Jimenez Millan and P. A. Ruiz-Ortiz, "La Cerrada de Utrero-Lanchar de Linarejos: Punto de Interes Geomor fologico en el Parque Natural de Cazorla, Segura Y Las Villas (Provincia de Jaen)," In: Estudios recientes (2000-2002) en Geomorfologia. Patrimonio, Montana y Dinamica Territorial, Valladolid, Dpto. Geografia-UVA, 2002, pp. 415-422.

[4] B. Joyce, "Volcanic Heritage of Southeastern Australia, and Its Value in Increasing Awareness of Volcanic Risk," VICMIN2001: The $3^{\text {rd }}$ Conference on Development in Victorian Geology and Mineralisation, AIG Bulletin, 2001, pp. 34-81.

[5] A. Drumm and A. Moore, "Developpement del Ecotouri- isme," Un Manuel Pour les Professionnels de la conservation. The Nature Conservancy, Arlington, Virginie, Etats-Unis, No. 1, 2003, pp. 1-102.

[6] A. Malaki, "Geosites: Interet Scientifique, Patrimoine Culturel et VisEes Socio-Economiques, au Niveau d'Ifrane, Azrou, Aîn Leuh et el Hajeb (Causse Moyen Atlasique)," Thèse de Doctorat, Faculté des Sciences de Rabat, Maroc, 2006, pp. 1-280.

[7] M. El Wartiti and M. Zahraoui, "Un Circuit pour la Promotion D'un Geo-Eco-Tourisme Integre dans le Plateau Central et le Moyen Atlas," 2ème workshop international WIGET 2, Proceeding Volume, 2010, pp. 126-165.

[8] M. Zahraoui, M. Aberkan and M. El Wartiti, "Les Formation Fluvio-Lacustre des Ait Hajji (Region de Tiddas-Maroc Central Mesetien,” Bulletin science de la Terre, No. 2, 1986, pp. 1-9.

[9] H. Rachidi, "Etude Petrologique du Volcanisme Recent du Plateau Central du Maroc,” Thése de $3^{\text {ème }}$ cycle, Paris Sud, 1983, pp. 1-142.

[10] M. El Azzouzi, "Volcanisme Calco-Alcalin et Alcalin en Contexte Post-Collision Continentale: Exemple du Maroc," Thèse de Doctorat d'Etat Es Sciences, Université Mohammed V-Agdal, Faculté des Sciences, Rabat, 2002, pp. 289. 